\title{
Adsorption Thermodynamic and Kinetic Studies of Methyl Orange onto Sugar Scum Powder as a Low-Cost Inorganic Adsorbent
}

\author{
Y. El maguana $(\mathbb{D}$, N. Elhadiri, M. Benchanaa, and R. Chikri \\ Research Laboratory on Materials Reactivity and Process Optimization (REMATOP), Department of Chemistry, \\ Faculty of Science Semlalia, Cadi Ayyad University, B.P. 2390, Marrakech, Morocco
}

Correspondence should be addressed to Y. El maguana; youssefelmaguana@gmail.com

Received 9 May 2020; Revised 20 May 2020; Accepted 21 May 2020; Published 27 June 2020

Academic Editor: José Morillo

Copyright (C) 2020 Y. El maguana et al. This is an open access article distributed under the Creative Commons Attribution License, which permits unrestricted use, distribution, and reproduction in any medium, provided the original work is properly cited.

\begin{abstract}
In the present study, batch adsorption experiments were carried out to investigate the removal of methyl orange (MO) from aqueous solution using sugar scum powder as an effective inorganic adsorbent which is a cheap precursor and abundant. The characteristics of this material were determined using XRD, SEM/EDX, and FTIR. The adsorption performance of sugar scum powder was evaluated using $\mathrm{MO}$ as the model adsorbate. Effects of various parameters such as initial dye concentration, contact time, and adsorbent dose were studied. The adsorption process can be best described by the pseudo-second-order kinetic and Langmuir adsorption isotherm models. Maximum monolayer adsorption capacity for MO removal was found to be $15.24 \mathrm{mg} / \mathrm{g}$ at temperature $22^{\circ} \mathrm{C}$ and $\mathrm{pH} 7.2$. Moreover, thermodynamic parameters suggested that the adsorption of MO onto sugar scum powder was a spontaneous and exothermic process. The results demonstrated that sugar scum is a suitable precursor for the preparation of efficient adsorbent for dye removal from wastewater.
\end{abstract}

\section{Introduction}

The rapidly growing population, along with improving economic growth, has brought serious problems including the continuous increase in the quantities of the agricultural byproducts and industrial wastes. The resulting wastes represent a significant environmental challenge if they are released to the environment without proper disposal procedure that may cause environmental pollution and harmful effects on human and animal health $[1,2]$. Thus, the scientific community has become increasingly interested in the waste management which can be valorized and used for various applications because they are abundant and renewable raw materials. Consequently, the agricultural byproducts and industrial wastes have been used for the production of adsorbents, of energy fuels through fermentation processes, of thermal energy by combustion, and of composts as fertilizer [3-8].
The use of industrial solid wastes as raw materials for the preparation of adsorbents has a positive impact in the protection of the environment by reducing solid wastes and also the production of low-cost adsorbents with high added value which can reduce contaminants in wastewater at a reasonable cost $[1,9,10]$. In fact, numerous studies have shown the possibility of using industrial solid wastes and agricultural byproducts as precursors for the preparation of efficient and inexpensive adsorbents. Thus, adsorbents have been prepared from clay materials [11], zeolites [12], siliceous material [13], marble dust [14], sewage sludge [12], chitosan and its derivatives [15-18], fly ash [19], wood sawdust [20], etc.

In addition to solid wastes, industries produce large volumes of wastewater that contain a wide variety of chemicals which affect, if discharged without any treatment, rivers, seas, lakes, and groundwater and therefore cause degradation of the ecosystem. Often, the chemicals 
contained in wastewater are nonbiodegradable, toxic, carcinogenic, and harmful to organisms even at low concentrations. Among these products, the dyes used in several sectors such as textiles, cosmetics, plastics, pigments units, leather, and paper industries have been considered as the primary pollutant due to their stability and low biodegradability [21]. Consequently, the scientific community has contributed to the treatment of industrial effluents by developing effective dye removal techniques. Adsorption is one of the mostly adopted techniques for dye removal from wastewater as it is found to be very effective and economical $[22,23]$. Therefore, many researches in recent years have demonstrated the potential use of various low-cost adsorbents for dye removal from wastewater such as magneticbased materials [16, 24-27], monolithic algal green powder [28], powdered marble [14], sepia shell-based composite [29], chelating resins [30], chitosan and its derivatives $[15,17,31]$, and biomass-based activated carbon [1, 20, 32].

Sugar scum is derived from the sugar-refining process through juice carbonation. It is separated from the sugary juices using filtration and disposed of in open fields. The aim of the present work is to study the potential of use of sugar scum for the removal of organic pollutants from aqueous solution. Toward this aim, the effect of various operating conditions on the MO removal was investigated in batch adsorption experiments.

\section{Materials and Methods}

2.1. Adsorbent. Sugar scum used in this study was coming from a discharge of sugar factory located in Sidi Bennour, Morocco. It was dried at $110^{\circ} \mathrm{C}$ for $24 \mathrm{~h}$ and crushed and sieved to obtain particle size less than $200 \mu \mathrm{m}$. Obtained material was used in the experiment without any pretreatment. All the chemicals used in this study were of analytical reagent grade.

2.2. Adsorption Experiments. Adsorption capacity of sugar scum was determined by performing batch mode adsorption. MO was chosen as an adsorbate to evaluate the adsorption characteristics of sugar scum powder and also serves as a model compound for adsorption of organic contaminants from aqueous solution. The effect of various parameters such as initial dye concentration, contact time, adsorbent dose, and temperature on the adsorption capacity of $\mathrm{MO}$ was studied. Batch adsorption experiments were performed in $100 \mathrm{~cm}^{3}$ flasks containing a defined amount of adsorbent and $50 \mathrm{~cm}^{3}$ of desired concentration of MO solution. These flasks were kept in a shaker of $180 \mathrm{rpm}$ at $22^{\circ} \mathrm{C}$. After adsorption, the residual concentration of $\mathrm{MO}$ was determined by spectrophotometric method (UV-3100PC spectrophotometer) at $462 \mathrm{~nm}$.

The amount of adsorption at equilibrium $\left(q_{\mathrm{e}}\right)$ was defined as the amount of adsorbate per gram of adsorbent (in $\mathrm{mg} / \mathrm{g}$ ) and was calculated using the following equation:

$$
q_{\mathrm{e}}=\frac{C_{0}-C_{\mathrm{e}}}{m} \times V
$$

The percentage removal $(R \%)$ of the methylene blue at equilibrium was calculated using the following relationship:

$$
R \%=\frac{C_{0}-C_{\mathrm{e}}}{C_{0}} \times 100,
$$

where $C_{0}$ and $C_{\mathrm{e}}$ (in $\mathrm{mg} / \mathrm{L}$ ) are the initial and equilibrium concentrations in aqueous solution, respectively, $V(L)$ is the volume of the solution, and $m(\mathrm{~g})$ is the mass of the adsorbent.

2.3. Characterization Techniques. X-ray powder diffraction (XRD) analysis of sugar scum powder was carried out in Reminex Managem laboratory in Morocco to identify the various phases present in this material. Scanning electron microscopy coupled with energy dispersive X-ray spectroscopy (SEM/EDX) was used to examine the morphology and the development of porosity of the sugar scum powder as well as to determine its elemental composition using TESCAN VEGA3-EDAX instrument with an accelerating voltage of $20 \mathrm{kV}$. The surface functional groups of the sugar scum powder were carried out by Fourier transformed infrared (FTIR) spectroscopy on a Nicolet 5700 spectrometer in the scanning range of 4000 to $400 \mathrm{~cm}^{-1}$ (64 scans, at a resolution of $4 \mathrm{~cm}^{-1}$ ).

\section{Results and Discussion}

3.1. Characterization of Sugar Scum. The phases present in the sugar scum powder are identified by comparing the XRD pattern of Figure 1 with the JCPDS data (Joint Committee for Powder Diffraction Standards). The XRD pattern shows an intense peak at $2 \theta=29.31^{\circ}$, which indicates that the calcite $\left(\mathrm{CaCO}_{3}\right)$ is the main phase present in sugar scum according to the JCPDS card no. 01-086-2339. This characteristic peak assigned to the calcite $\left(\mathrm{CaCO}_{3}\right)$ has also been observed by other authors $[33,34]$. In addition, other peaks located at $2 \theta=23.01,31.31,35.97,39.40,43.13,47.37,48.39,56.59$, $57.37,60.67,63.01,64.62$, and 65.37 were matched with the JCPDS card no. 01-086-2339.

The scanning electron microscopy (SEM) was used to observe the surface morphology of sugar scum powder. Figure 2 shows the SEM photograph of this adsorbent. It can be seen that the sugar scum powder is formed of various sizes of agglomerated particles with irregular shapes and has a porous texture. The results of the elemental analysis using EDX (Figure 3) indicate that the major elements present in the sugar scum are oxygen $(45.73 \%)$, calcium $(32.99 \%)$, and carbon (16.96\%).

Figure 4 corresponds to the FTIR spectra of sugar scum powder. The band located at around $3424 \mathrm{~cm}^{-1}$ is attributed to $\mathrm{O}-\mathrm{H}$ stretching vibration of the adsorbed water [21]. The peaks at $713,874,1078,1424$, and $2511 \mathrm{~cm}^{-1}$ are typically attributed to the calcite $\left(\mathrm{CaCO}_{3}\right)$ [21, 35-37]. Finally, the band caused by the bending vibrations of strongly adsorbed water is located at $1630 \mathrm{~cm}^{-1}$. 


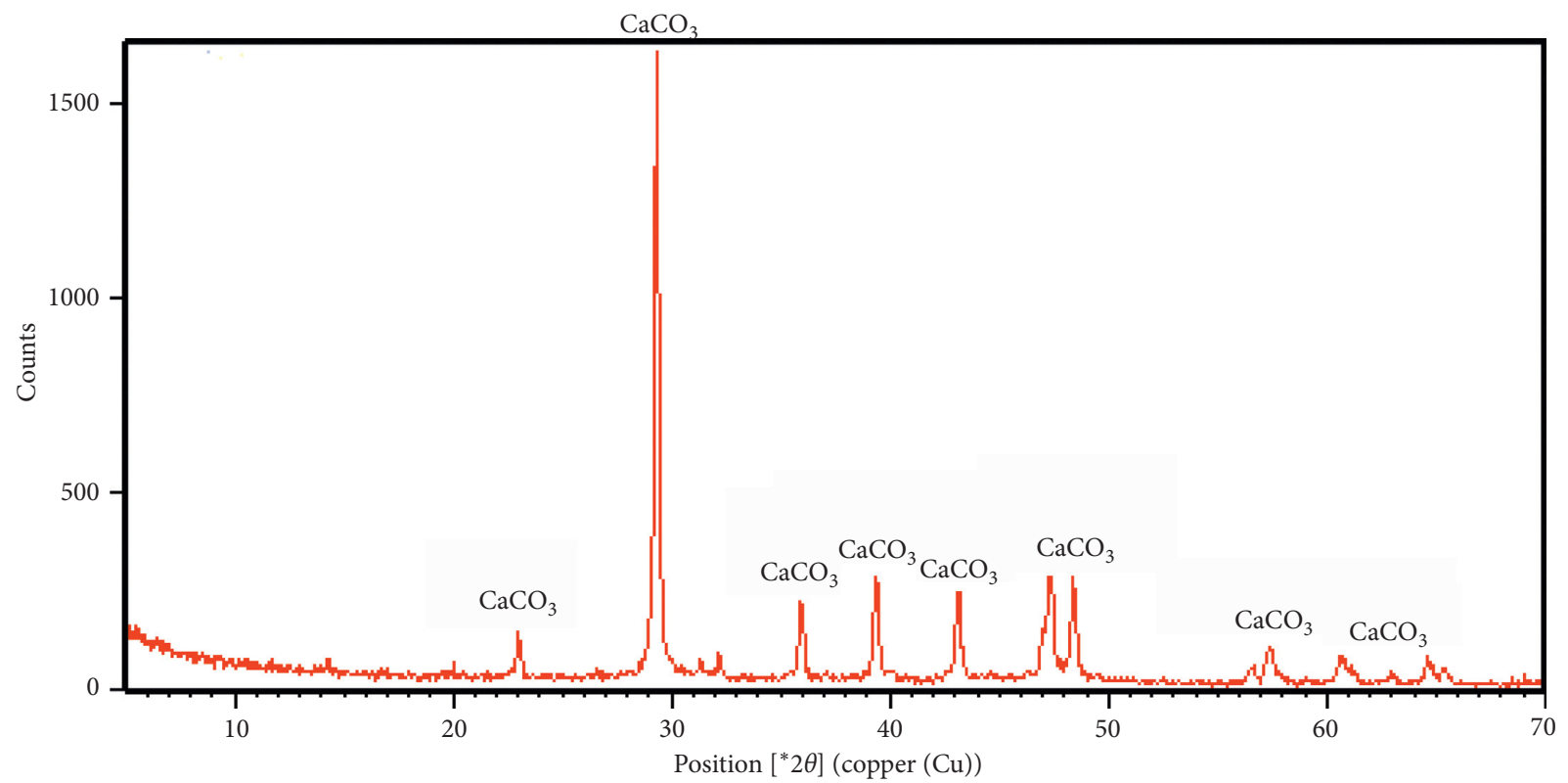

FIgURE 1: XRD patterns of sugar scum powder.

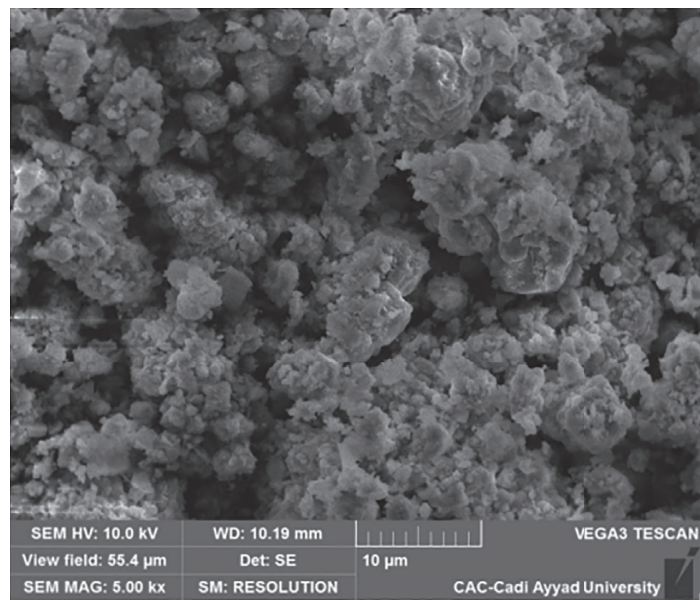

FIGURE 2: SEM of sugar scum powder.

\subsection{Study of the Influence of Some Factors on the Removal of MO}

3.2.1. Effect of Initial MO Concentration. The effect of increasing initial MO concentration on adsorption capacity of sugar scum is shown in Figure 5. As can be seen, the adsorption capacity increased with an increase in the initial concentration of MO solution if the amount of adsorbent was kept unchanged. This is due to the increase in the diffusion rate of $\mathrm{MO}$ with the increase in the concentration gradient between the aqueous solution and the solid phase [21].

3.2.2. Effect of Adsorbent Dose. The effect of the adsorbent dose, ranging from 1 to $16 \mathrm{~g} / \mathrm{L}$, on the adsorption of $\mathrm{MO}$ is illustrated in Figure 6. The MO removal increases as the amount of the sugar scum powder in solution increases and reaches a maximum value $80 \%$ at $16 \mathrm{~g} / \mathrm{L}$. This observation can be explained by the increase in the surface area of the adsorbents and hence the number of available adsorption sites for the adsorption of MO [21]. Therefore, sugar scum dosage of $16 \mathrm{~g} / \mathrm{L}$ was chosen as maximum removal for $100 \mathrm{mg} / \mathrm{L} \mathrm{MO}$ dye solution for further studies.

3.2.3. Effect of Contact Time. The adsorption of MO onto sugar scum powder is presented in Figure 7 as a function of contact time from $15 \mathrm{~min}$ to $180 \mathrm{~min}$. It is clear from the figure that the adsorption process was fast in the first $20 \mathrm{~min}$ and more than $80 \%$ of MO was adsorbed in this period. The adsorption process of $\mathrm{MO}$ was rapid at the initial stage due to the availability of vacant sites on the exterior surfaces. After the saturation of those active sites, MO entered to the pores of the adsorbent with a slower rate to reach equilibrium time [21]. The equilibrium state was established almost after $30 \mathrm{~min}$. In the subsequent batch experiments, $60 \mathrm{~min}$ was taken to ensure the adsorption equilibrium.

3.3. Adsorption Kinetics Models. Adsorption kinetics models provide invaluable information on the controlling mechanisms of adsorption process. The overall adsorption process may be controlled either by external or film diffusion, pore diffusion and adsorption on the pore surface, or a combination of more than one step.

In order to predict the mechanism of the adsorption process of MO onto the sugar scum powder, the experimental data were fitted by the pseudo-first-order [38], pseudo-second-order [39], and intraparticle diffusion [40] models.

The linear pseudo-first-order model is given by the following equation:

$$
\ln \left(q_{\mathrm{e}}-q_{t}\right)=\ln q_{\mathrm{e}}-k_{1} t
$$




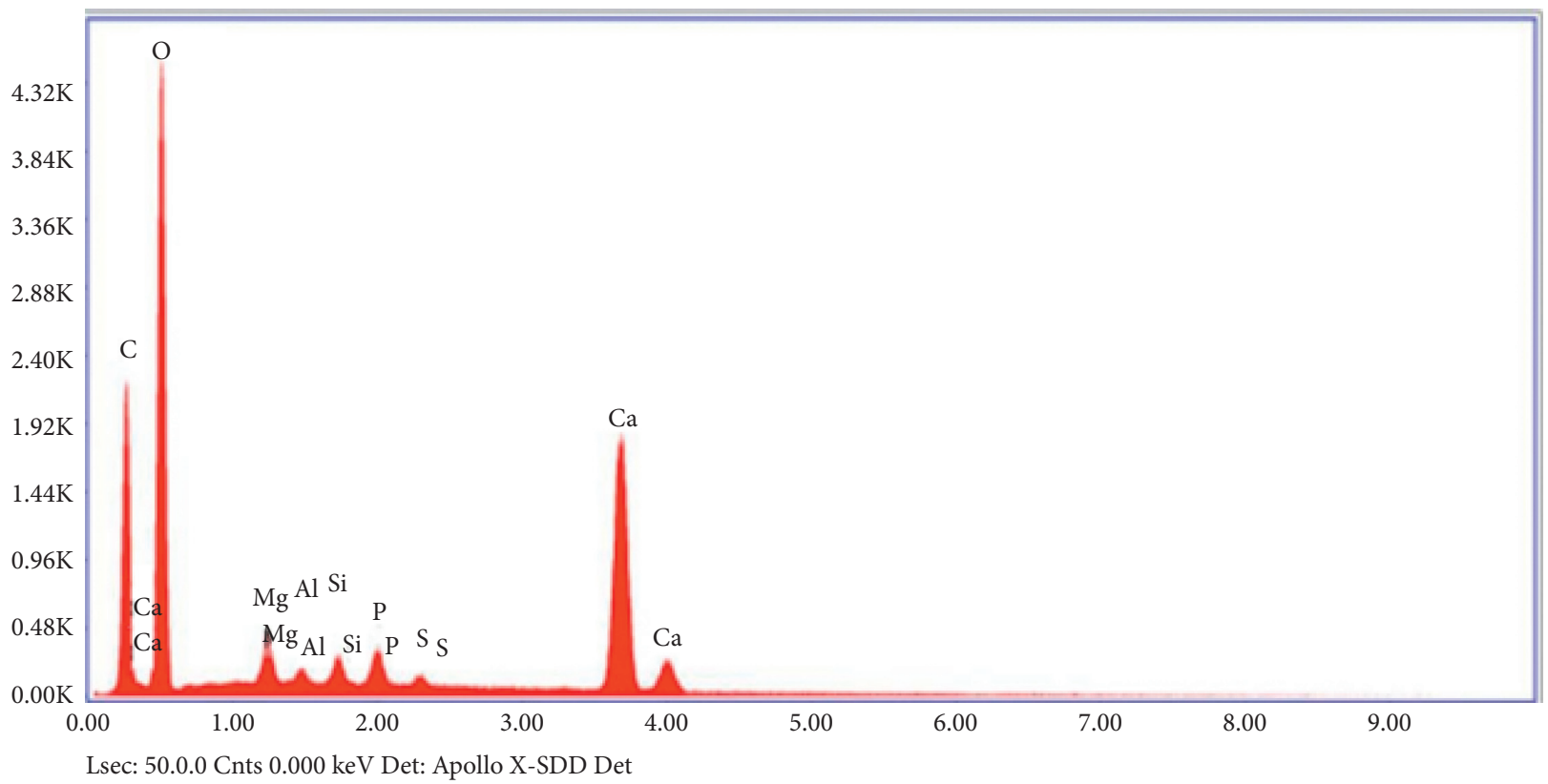

Figure 3: EDX of sugar scum powder.

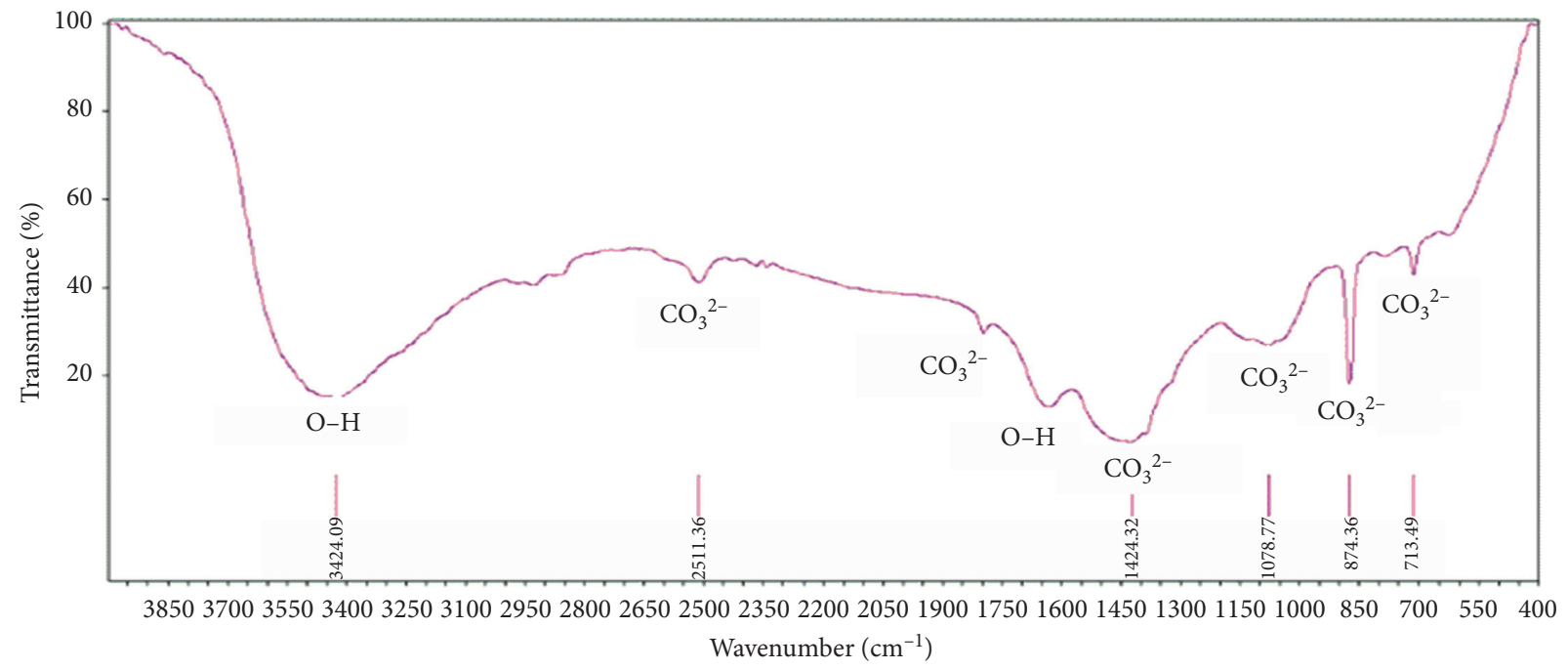

FIgURE 4: FTIR spectra of sugar scum powder.

where $q_{\mathrm{e}}(\mathrm{mg} / \mathrm{g})$ is the adsorption amount at equilibrium, $q_{\mathrm{t}}$ $(\mathrm{mg} / \mathrm{g})$ is the adsorption amount at time $t(\mathrm{~min})$, and $k_{1}$ $\left(\mathrm{min}^{-1}\right)$ is the adsorption rate constant of pseudo-first-order model. Kinetic parameters, $q_{\mathrm{e}}$ and $k_{1}$, can be determined experimentally from the slope and intercept of the plot $\ln \left(q_{\mathrm{e}}-q_{t}\right)$ versus $t$ (Figure 8).

The linear pseudo-second-order equation is given as follows:

$$
\frac{t}{q_{t}}=\frac{1}{k_{2} q_{\mathrm{e}}^{2}}+\frac{t}{q_{\mathrm{e}}}
$$

where $q_{\mathrm{e}}(\mathrm{mg} / \mathrm{g})$ is the adsorption amount at equilibrium, $q_{\mathrm{t}}(\mathrm{mg} / \mathrm{g})$ is the adsorption amount at time $t(\mathrm{~min})$, and $k_{2}$ $(\mathrm{g} / \mathrm{mg} \mathrm{min})$ is the adsorption rate constant of pseudo- second-order model. Kinetic parameters, $q_{\mathrm{e}}$ and $k_{2}$, can be obtained experimentally by plotting $\ln \left(q_{\mathrm{e}}-q_{t}\right)$ as a function of $t$ (Figure 8).

The intraparticle diffusion model is expressed as follows:

$$
q_{t}=k_{\mathrm{id}} t^{1 / 2}+c
$$

where $q_{\mathrm{t}}(\mathrm{mg} / \mathrm{g})$ is the adsorption amount at time $t$ (min), $k_{\text {id }}\left(\mathrm{mg} / \mathrm{g} \mathrm{min}^{1 / 2}\right)$ is the adsorption rate constant of intraparticle diffusion model, and $c$ is a constant related to the thickness of the boundary layer.

The calculated kinetic parameters of pseudo-first-order and pseudo-second-order equations are summarized in Table 1. The results showed that the fitting data to the pseudo-second-order model gave a high value of correlation 


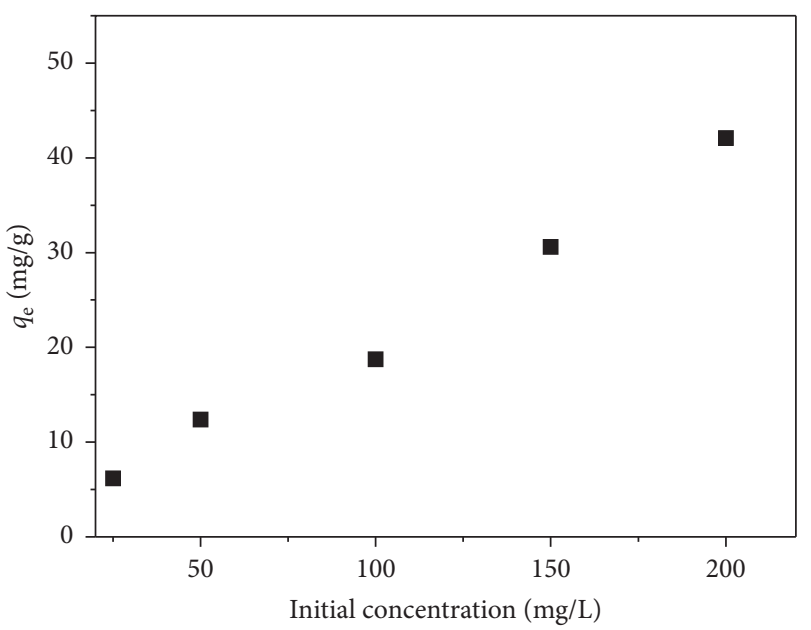

FIgURe 5: Effect of initial $\mathrm{MO}$ concentration $\left(t_{\text {contact }}=24 \mathrm{~h}\right.$; adsorbent dose $\left.=4 \mathrm{~g} / \mathrm{L} ; \mathrm{pH}=7.2 ; T=22^{\circ} \mathrm{C}\right)$.

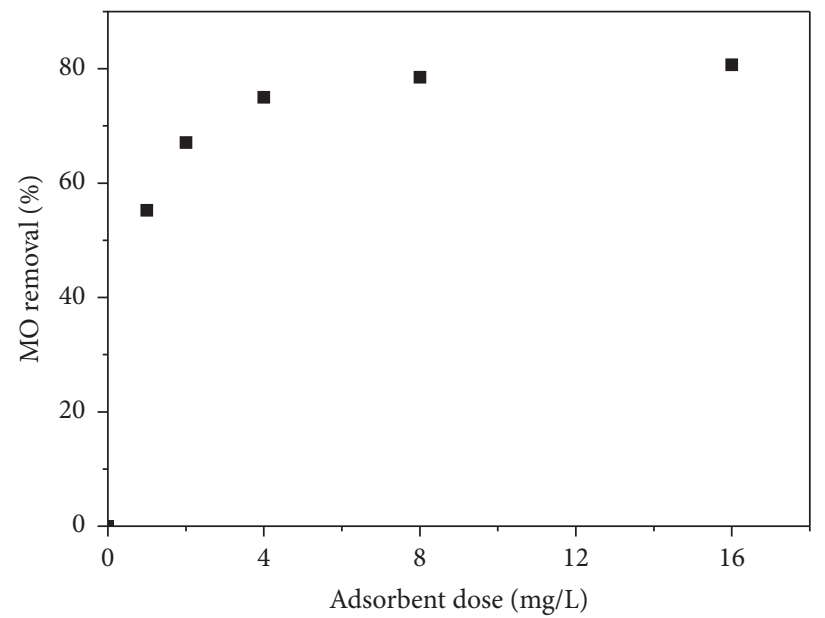

Figure 6: Effect of adsorbent dose on the adsorption of $\mathrm{MO}\left(t_{\text {contact }}=24 \mathrm{~h} ; C_{0}=100 \mathrm{mg} / \mathrm{L} ; \mathrm{pH}=7.21 ; T=22^{\circ} \mathrm{C}\right)$.

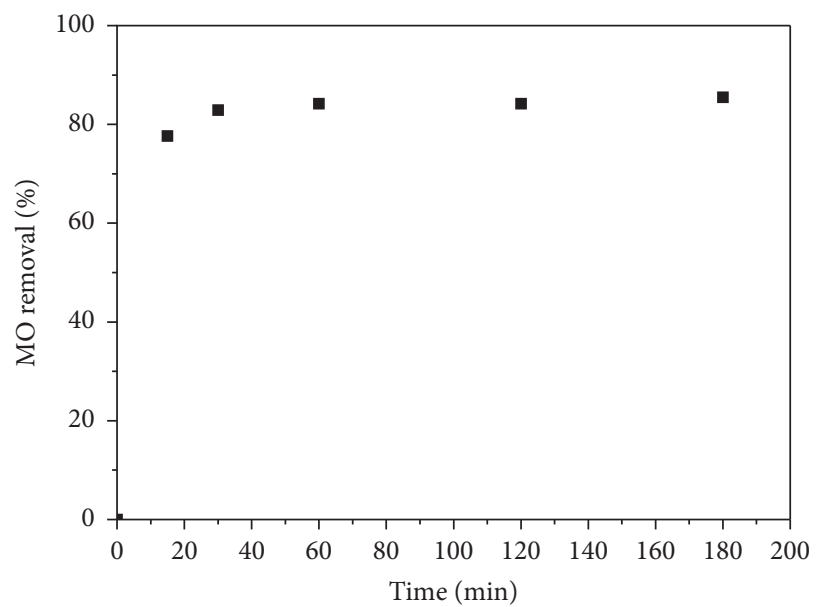

Figure 7: Effect of contact time on the adsorption of $\mathrm{MO}\left(C_{0}=100 \mathrm{mg} / \mathrm{L} ;\right.$ adsorbent dose $\left.=16 \mathrm{~g} / \mathrm{L} ; \mathrm{pH}=7.21 ; T=22^{\circ} \mathrm{C}\right)$.

coefficient $R^{2}$, and its calculated equilibrium adsorption capacity $\left(q_{\mathrm{e}, \mathrm{cal}}\right)$ is closer to the experimental value $\left(q_{\mathrm{e}, \exp }=5.32 \mathrm{mg} / \mathrm{g}\right.$ which corresponds to $84 \%$ of $\mathrm{MO}$ removal). Therefore, the pseudo-second-order model can describe the adsorption process of MO onto sugar scum powder. These results suggest that the boundary layer 


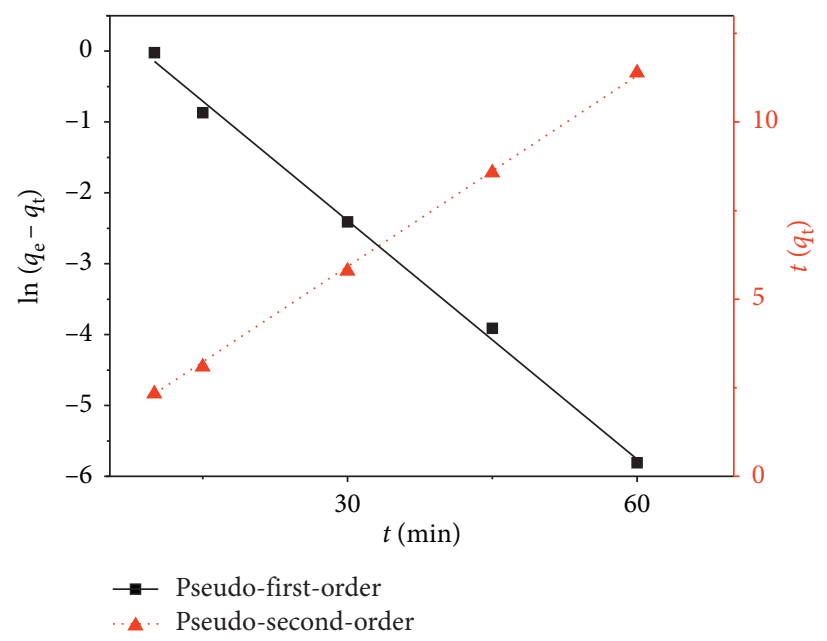

FIGURE 8: Linear fits of pseudo-first-order and pseudo-second-order kinetics for MO adsorption onto sugar scum powder $\left(C_{0}=100 \mathrm{mg} / \mathrm{L}\right.$; adsorbent dose $=16 \mathrm{~g} / \mathrm{L} ; \mathrm{pH}=7.21 ; T=22^{\circ} \mathrm{C}$ ).

TABLE 1: Kinetic parameters for the $\mathrm{MO}$ adsorption onto sugar scum powder $\left(C_{0}=100 \mathrm{mg} / \mathrm{L}\right.$; adsorbent dose $\left.=16 \mathrm{~g} / \mathrm{L} ; \mathrm{pH}=7.21 ; T=22^{\circ} \mathrm{C}\right)$.

\begin{tabular}{lcccccc}
\hline & & Pseudo-first-order & \multicolumn{3}{c}{ Pseudo-second-order } \\
$q_{\mathrm{e}, \exp }(\mathrm{mg} / \mathrm{g})$ & $q_{\mathrm{e}, \mathrm{cal}}(\mathrm{mg} / \mathrm{g})$ & $k_{1}(1 / \mathrm{min})$ & $R^{2}$ & $q_{\mathrm{e}, \mathrm{cal}}(\mathrm{mg} / \mathrm{g})$ & $k_{2}(\mathrm{~g} / \mathrm{mg} \mathrm{min})$ & 0.0051 \\
\hline 5.32 & 2.65 & 0.1118 & 0.99 & 5.49 & $R^{2}$ \\
\hline
\end{tabular}

resistance was not the rate-limiting step; it is a process in which a rapid initial stage is followed by a slower second stage limited by the intraparticle diffusion into smaller pores $[21,41]$.

The plot of the intraparticle diffusion model is shown in Figure 9. It can be observed that the plot is not linear over the whole time range, having three linear segments, which indicated that intraparticle diffusion was not the only ratelimiting step of the adsorption process, but there are other mechanisms which may control the rate of adsorption, all of which may be operating simultaneously $[20,42]$. The initial part of the plot is attributed to the diffusion of MO through the solution to the external surface of the adsorbent. Thereafter, the second portion could be attributed to the intraparticle diffusion process. The slope of the linear portion indicates the rate of the adsorption process: the lower slope corresponds to a slower adsorption process [43]. The slope of the first portion was higher than that of the second portion which indicates that the MO molecules are quickly diffused through the boundary layer than through the pores of the adsorbent. Initially, the MO molecules are rapidly adsorbed on the surface of the sugar scum powder, and when saturation is reached, the MO particles are diffused into the internal surface of the particles of adsorbent. The third portion is attributed to the final equilibrium stage for which the intraparticle diffusion starts to slow $[20,44]$.

3.4. Adsorption Isotherms. The adsorption isotherm describes the interaction between the adsorbate molecules and the adsorbent when the system reaches the equilibrium. It provides the qualitative information on the nature of adsorbate-adsorbent surface interactions and could be used to evaluate the adsorption capacity. In this study, the experimental data were fitted to the Langmuir and Freundlich models to find which one can be used to describe the adsorption process of $\mathrm{MO}$ on the surface of sugar scum powder. Langmuir equation was based on the assumption of monolayer adsorption on a homogeneous surface without interaction between adsorbates, while the Freundlich isotherm assumes the multilayer adsorption on heterogeneous surface [1].

The linear form of Langmuir isotherm equation is given as

$$
\frac{1}{q_{\mathrm{e}}}=\frac{1}{q_{\mathrm{m}}}+\frac{1}{K_{\mathrm{L}} q_{\mathrm{m}}} \times \frac{1}{C_{\mathrm{e}}} .
$$

The linear form of Freundlich isotherm equation is expressed as

$$
\ln q_{\mathrm{e}}=\ln K_{\mathrm{F}}+\frac{1}{n} \ln C_{\mathrm{e}},
$$

where $C_{\mathrm{e}}$ is the equilibrium concentration of adsorbate, $q_{\mathrm{e}}$ is the amount of adsorption at the equilibrium, $q_{\mathrm{m}}$ is the monolayer adsorption capacity, $n$ is the Freundlich intensity constant, and $K_{\mathrm{L}}$ and $K_{\mathrm{F}}$ are the Langmuir and Freundlich constants, respectively.

The adsorption isotherm of $\mathrm{MO}$ onto sugar scum powder obtained at temperature $22^{\circ} \mathrm{C}$ is presented in Figure 10. According to Giles classification [45], this isotherm displayed an $\mathrm{H}$ curve pattern, indicating that the $\mathrm{MO}$ and sugar scum powder have a high affinity.

Table 2 summarizes the calculated parameters of Langmuir and Freundlich isotherms obtained by linear fitting (Figure 11). The results given in Table 2 show that the adsorption isotherm of $\mathrm{MO}$ onto the sugar scum powder is described by the Langmuir model with a correlation 


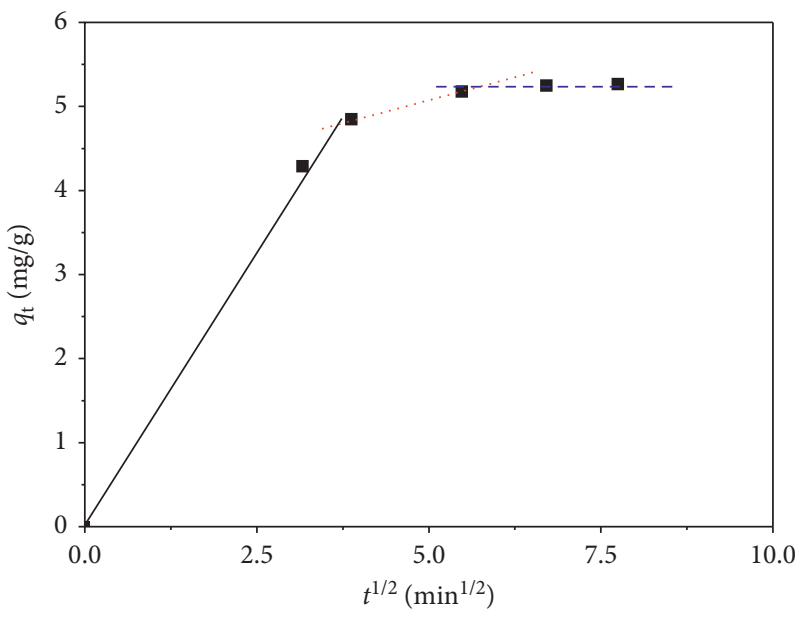

- Experimental data

Figure 9: Plot of the intraparticle diffusion model for MO adsorption onto sugar scum powder $\left(C_{0}=100 \mathrm{mg} / \mathrm{L}\right.$; adsorbent dose $=16 \mathrm{~g} / \mathrm{L}$; $\left.\mathrm{pH}=7.21 ; T=22^{\circ} \mathrm{C}\right)$.

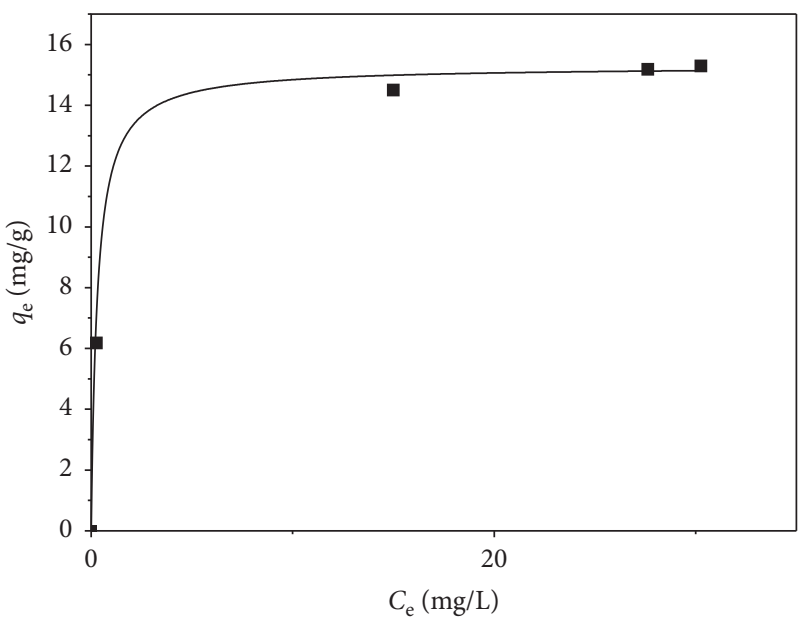

Figure 10: Adsorption isotherm of $\mathrm{MO}$ onto sugar scum powder (adsorbent dose $=16 \mathrm{~g} / \mathrm{L} ; \mathrm{pH}=7.21 ; \mathrm{T}=22^{\circ} \mathrm{C}$ ).

TABLe 2: Langmuir and Freundlich isotherm parameters (adsorbent dose $=16 \mathrm{~g} / \mathrm{L} ; \mathrm{pH}=7.21 ; T=22^{\circ} \mathrm{C}$ ).

\begin{tabular}{lccccc}
\hline & Langmuir & & Freundlich & \\
$q_{\mathrm{m}}(\mathrm{mg} / \mathrm{g})$ & $K_{\mathrm{L}}(\mathrm{L} / \mathrm{mg})$ & $R^{2}$ & $1 / n$ & $K_{\mathrm{F}}\left((\mathrm{mg} / \mathrm{g})(\mathrm{L} / \mathrm{mg})^{1 / n}\right)$ & $R^{2}$ \\
\hline 15.24 & 2.6223 & 0.99 & 0.1948 & 8.0975 & 0.98 \\
\hline
\end{tabular}

coefficient $\left(R^{2}\right)$ greater than 0.99 , suggesting monolayer adsorption on homogeneous surface without interaction between adsorbates. The maximum monolayer capacity for the $\mathrm{MO}$ adsorption onto sugar scum powder was found to be $15.24 \mathrm{mg} / \mathrm{g}$ at $22^{\circ} \mathrm{C}$.

3.5. Thermodynamic Study. The nature and thermodynamic feasibility of MO adsorption onto sugar scum powder were evaluated by calculating the thermodynamic parameters from the experimental data obtained at various temperatures. The standard free energy change $\left(\Delta G^{\circ}\right)$, enthalpy $\left(\Delta H^{\circ}\right)$, and entrophy $\left(\Delta S^{\circ}\right)$ are obtained by using the following equations:

$$
\begin{aligned}
K_{\mathrm{d}} & =\frac{q_{\mathrm{e}}}{C_{\mathrm{e}}} \\
\Delta G^{\circ} & =-\mathrm{RT} \ln \left(1000 K_{\mathrm{d}}\right), \\
\ln \left(1000 K_{\mathrm{d}}\right) & =-\frac{\Delta H^{\circ}}{\mathrm{RT}}+\frac{\Delta S^{\circ}}{R},
\end{aligned}
$$




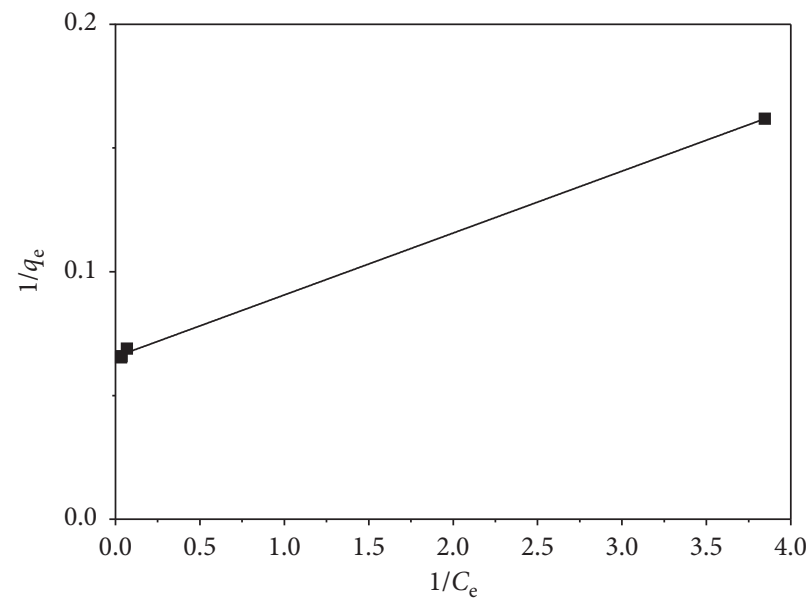

(a)

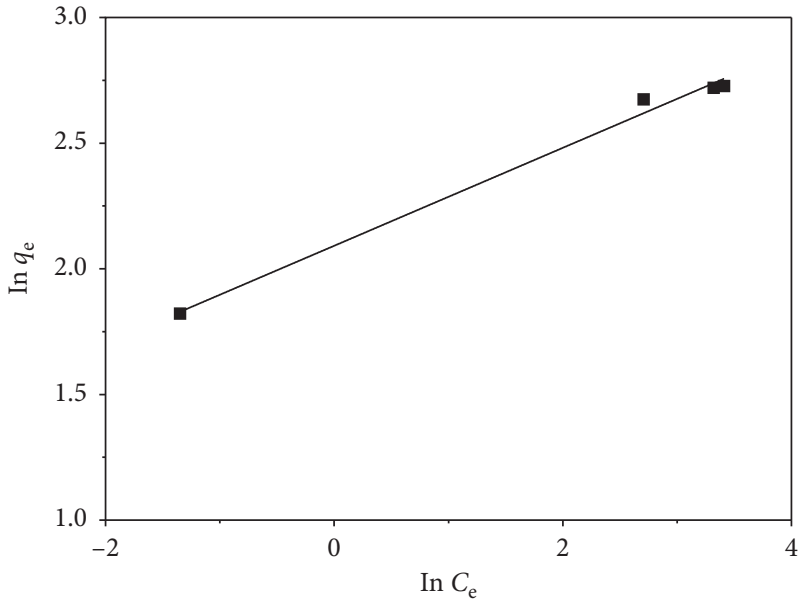

(b)

FIgURE 11: Linear modeling of the MO adsorption isotherm onto sugar scum powder (adsorbent dose $\left.=16 \mathrm{~g} / \mathrm{L} ; \mathrm{pH}=7.21 ; T=22^{\circ} \mathrm{C}\right):(\mathrm{a})$ Langmuir; (b) Freundlich.

TABLE 3: Thermodynamic parameters for MB adsorption on optimal activated carbon $\left(C_{0}=100 \mathrm{mg} / \mathrm{L}\right.$; adsorbent dose $=16 \mathrm{~g} / \mathrm{L}$; $\mathrm{pH}=7.21$ ).

\begin{tabular}{lccc}
\hline Temperature $(\mathrm{K})$ & $\Delta G^{\circ}(\mathrm{kJ} / \mathrm{mol})$ & $\Delta H^{\circ}(\mathrm{kJ} / \mathrm{mol})$ & $\Delta S^{\circ}(\mathrm{J} / \mathrm{K} \mathrm{mol})$ \\
\hline 293 & -14.63 & -14.14 & 2.03 \\
303 & -14.9 & & \\
318 & -14.73 & & \\
\hline
\end{tabular}

where $K_{\mathrm{d}}$ is the thermodynamic distribution coefficient, $R$ is the universal gas constant $(8.314 \mathrm{~J} / \mathrm{mol} \mathrm{K})$, and $T$ is the absolute temperature (K). The values of $\Delta H^{\circ}$ and $\Delta S^{\circ}$ can be determined from the slope and intercept of the plot of $\ln \left(1000 K_{d}\right)$ versus $1 / T$.

The values of $\Delta G^{\circ}, \Delta H^{\circ}$, and $\Delta S^{\circ}$ were calculated and are listed in Table 3. The negative values of $\Delta G^{\circ}$ indicate the feasibility and spontaneous of the adsorption processes of MO onto sugar scum powder. The negative value of $\Delta H^{\circ}$ indicates the exothermic and physical nature of the adsorption process involving weak forces of attraction between MO molecules and sugar scum powder [46]. The positive value of $\Delta S^{\circ}$ indicates the increased randomness at the solidsolution interface during the fixation of the $\mathrm{MO}$ on the active sites of the studied adsorbent.

\section{Conclusion}

The present study shows that the sugar scum is a cheap and effective inorganic adsorbent for the removal of anionic dyes such as methyl orange from aqueous solutions. The adsorption kinetics is fast with 60 min needed to reach equilibrium, and more than $80 \%$ of MO was adsorbed in the first $20 \mathrm{~min}$. The adsorption of MO can be described by a pseudosecond-order model, and thermodynamic analysis shows that the adsorption is an exothermic process. The equilibrium data were best described by the Langmuir isotherm model, with a maximum adsorption capacity of $15.24 \mathrm{mg} / \mathrm{g}$. As a result of this study, sugar scum powder can be used as an effective adsorbent for the removal of anionic dyes from wastewater.

\section{Data Availability}

All the data used to support the findings of this study are included within the article.

\section{Conflicts of Interest}

The authors declare that they have no conflicts of interest.

\section{Acknowledgments}

We are grateful to the Center of Analyses and Characterization (CAC) of University Caddy Ayyad, Morocco. Also, our respectful thanks go to professors of REMATOP, LCOA, and Reminex Managem Laboratories in Marrakech, Morocco.

\section{References}

[1] Y. El Maguana, N. Elhadiri, M. Bouchdoug, M. Benchanaa, and A. Jaouad, "Activated carbon from prickly pear seed cake: optimization of preparation conditions using experimental design and its application in dye removal," International Journal of Chemical Engineering, vol. 2019, Article ID 8621951, 12 pages, 2019.

[2] L. Ajam, M. Ben Ouezdou, H. S. Felfoul, and R. E. Mensi, "Characterization of the Tunisian phosphogypsum and its valorization in clay bricks," Construction and Building Materials, vol. 23, no. 10, pp. 3240-3247, 2009.

[3] A. Cerda, A. Artola, X. Font, R. Barrena, T. Gea, and A. Sánchez, "Composting of food wastes: status and challenges," Bioresource Technology, vol. 248, pp. 57-67, 2018.

[4] R. K. Gautam, A. Mudhoo, G. Lofrano, and M. C. Chattopadhyaya, "Biomass-derived biosorbents for metal ions sequestration: adsorbent modification and activation methods and adsorbent regeneration," Journal of 
Environmental Chemical Engineering, vol. 2, no. 1, pp. 239259, 2014.

[5] C. Du, J. J. Abdullah, D. Greetham et al., "Valorization of food waste into biofertiliser and its field application," Journal of Cleaner Production, vol. 187, pp. 273-284, 2018.

[6] D. Marcelo, W. Bizzo, M. Alamo, and E. Vásquez, "Assessment of sugarcane byproducts for energy use in Peru," Energy Procedia, vol. 115, pp. 397-408, 2017.

[7] P. N. Omo-Okoro, A. P. Daso, and J. O. Okonkwo, "A review of the application of agricultural wastes as precursor materials for the adsorption of per- and polyfluoroalkyl substances: a focus on current approaches and methodologies," Environmental Technology é Innovation, vol. 9, pp. 100-114, 2018.

[8] M. T. Yagub, T. K. Sen, S. Afroze, and H. M. Ang, "Dye and its removal from aqueous solution by adsorption: a review," Advances in Colloid and Interface Science, vol. 209, pp. 172184, 2014.

[9] K. Ennaciri, A. Baçaoui, M. Sergent, and A. Yaacoubi, “Application of fractional factorial and Doehlert designs for optimizing the preparation of activated carbons from Argan shells," Chemometrics and Intelligent Laboratory Systems, vol. 139, pp. 48-57, 2014

[10] S. Athalathil, F. Stüber, C. Bengoa, J. Font, A. Fortuny, and A. Fabregat, "Characterization and performance of carbonaceous materials obtained from exhausted sludges for the anaerobic biodecolorization of the azo dye acid Orange II," Journal of Hazardous Materials, vol. 267, pp. 21-30, 2014.

[11] A. Kausar, M. Iqbal, A. Javed et al., "Dyes adsorption using clay and modified clay: a review," Journal of Molecular Liquids, vol. 256, pp. 395-407, 2018.

[12] N. Setthaya, P. Chindaprasirt, S. Yin, and K. Pimraksa, " $\mathrm{TiO}_{2}{ }^{-}$ zeolite photocatalysts made of metakaolin and rice husk ash for removal of methylene blue dye," Powder Technology, vol. 313, pp. 417-426, 2017.

[13] J. Y. Kim, S. H. Park, and J.-S. Yu, "Anchoring of dye molecules into mesoporous siliceous MCM-48," Optical Materials, vol. 21, no. 1-3, pp. 349-352, 2003.

[14] Y. El maguana, N. Elhadiri, M. Bouchdoug, and M. Benchanaa, "Valorization of powdered marble as an adsorbent for removal of methylene blue using response surface methodology," Applied Journal of Environmental Engineering Science, vol. 1, pp. 53-65, 2019.

[15] K. Z. Elwakeel, S. El-Kousy, H. G. El-Shorbagy, and M. A. A. El-Ghaffar, "Comparison between the removal of Reactive Black 5 from aqueous solutions by 3 -amino-1,2,4 triazole,5-thiol and melamine grafted chitosan prepared through four different routes," Journal of Environmental Chemical Engineering, vol. 4, no. 1, pp. 733-745, 2016.

[16] K. Z. Elwakeel, "Removal of Reactive Black 5 from aqueous solutions using magnetic chitosan resins," Journal of Hazardous Materials, vol. 167, no. 1-3, pp. 383-392, 2009.

[17] K. Z. Elwakeel, M. A. Abd El-Ghaffar, S. M. El-kousy, and H. G. El-Shorbagy, "Synthesis of new ammonium chitosan derivatives and their application for dye removal from aqueous media," Chemical Engineering Journal, vol. 203, pp. 458-468, 2012.

[18] C. Li, T. Lou, X. Yan, Y.-z. Long, G. Cui, and X. Wang, "Fabrication of pure chitosan nanofibrous membranes as effective absorbent for dye removal," International Journal of Biological Macromolecules, vol. 106, pp. 768-774, 2018.

[19] S. Wang, Y. Boyjoo, A. Choueib, and Z. H. Zhu, "Removal of dyes from aqueous solution using fly ash and red mud," Water Research, vol. 39, no. 1, pp. 129-138, 2005.
[20] K. Y. Foo and B. H. Hameed, "Mesoporous activated carbon from wood sawdust by $\mathrm{K}_{2} \mathrm{CO}_{3}$ activation using microwave heating," Bioresource Technology, vol. 111, pp. 425-432, 2012.

[21] Y. El maguana, N. Elhadiri, M. Bouchdoug, M. Benchanaa, and A. Boussetta, "Optimization of preparation conditions of novel adsorbent from sugar scum using response surface methodology for removal of methylene blue," Journal of Chemistry, vol. 2018, pp. 1-10, 2018.

[22] K. S. Bharathi and S. T. Ramesh, "Removal of dyes using agricultural waste as low-cost adsorbents: a review," Applied Water Science, vol. 3, no. 4, pp. 773-790, 2013.

[23] S. Elabbas, L. Mandi, F. Berrekhis, M. N. Pons, J. P. Leclerc, and N. Ouazzani, "Removal of $\mathrm{Cr}$ (III) from chrome tanning wastewater by adsorption using two natural carbonaceous materials: eggshell and powdered marble," Journal of Environmental Management, vol. 166, pp. 589-595, 2016.

[24] K. Z. Elwakeel, A. A. El-Bindary, A. Ismail, and A. M. Morshidy, "Sorptive removal of Remazol Brilliant Blue $\mathrm{R}$ from aqueous solution by diethylenetriamine functionalized magnetic macro-reticular hybrid material," RSC Advances, vol. 6, no. 27, pp. 22395-22410, 2016.

[25] K. Z. Elwakeel, A. A. El-Bindary, A. Z. El-Sonbati, and A. R. Hawas, "Adsorption of toxic acidic dye from aqueous solution onto diethylenetriamine functionalized magnetic glycidyl methacrylate- $\mathrm{N}, \mathrm{N}^{\prime}$-methylenebisacrylamide," RSC Advances, vol. 6, no. 4, pp. 3350-3361, 2016.

[26] K. Z. Elwakeel, A. Shahat, Z. A. Khan, W. Alshitari, and E. Guibal, "Magnetic metal oxide-organic framework material for ultrasonic-assisted sorption of titan yellow and rose bengal from aqueous solutions," Chemical Engineering Journal, vol. 392, p. 123635, 2020.

[27] A. A. Yakout, M. A. Shaker, K. Z. Elwakeel, and W. Alshitari, "Lauryl sulfate@magnetic graphene oxide nanosorbent for fast methylene blue recovery from aqueous solutions," Journal of Dispersion Science and Technology, vol. 40, no. 5, pp. 707-715, 2019.

[28] A. M. Elgarahy, K. Z. Elwakeel, G. A. Elshoubaky, and S. H. Mohammad, "Microwave-accelerated sorption of cationic dyes onto green marine algal biomass," Environmental Science and Pollution Research, vol. 26, no. 22, pp. 2270422722, 2019.

[29] A. M. Elgarahy, K. Z. Elwakeel, G. A. Elshoubaky, and S. H. Mohammad, "Untapped sepia shell-based composite for the sorption of cationic and anionic dyes," Water, Air, \& Soil Pollution, vol. 230, p. 217, 2019.

[30] K. Z. Elwakeel and M. Rekaby, "Efficient removal of Reactive Black 5 from aqueous media using glycidyl methacrylate resin modified with tetraethelenepentamine," Journal of Hazardous Materials, vol. 188, no. 1-3, pp. 10-18, 2011.

[31] K. Z. Elwakeel, M. A. Abd El-Ghaffar, S. M. El-Kousy, and H. G. El-Shorbagy, "Enhanced remediation of reactive black 5 from aqueous media using new chitosan ion exchangers," Journal of Dispersion Science and Technology, vol. 34, no. 7, pp. 1008-1019, 2013.

[32] K. Z. Elwakeel, G. O. El-Sayed, and S. M. Abo El-Nassr, "Removal of ferrous and manganous from water by activated carbon obtained from sugarcane bagasse," Desalination and Water Treatment, vol. 55, no. 2, pp. 471-483, 2015.

[33] S. Chraibi, H. Moussout, F. Boukhlifi, H. Ahlafi, and M. Alami, "Utilization of calcined eggshell waste as an adsorbent for the removal of phenol from aqueous solution," Journal of Encapsulation and Adsorption Sciences, vol. 6, no. 4, pp. 132-146, 2016. 
[34] M. T. Islam, R. Saenz-Arana, C. Hernandez et al., "Conversion of waste tire rubber into a high-capacity adsorbent for the removal of methylene blue, methyl orange, and tetracycline from water," Journal of Environmental Chemical Engineering, vol. 6, no. 2, pp. 3070-3082, 2018.

[35] M. M. Hamed, I. M. Ahmed, and S. S. Metwally, "Adsorptive removal of methylene blue as organic pollutant by marble dust as eco-friendly sorbent," Journal of Industrial and Engineering Chemistry, vol. 20, no. 4, pp. 2370-2377, 2014.

[36] D. Mehta, P. Mondal, and S. George, "Utilization of marble waste powder as a novel adsorbent for removal of fluoride ions from aqueous solution," Journal of Environmental Chemical Engineering, vol. 4, no. 1, pp. 932-942, 2016.

[37] S. Maleki Dizaj, F. Lotfipour, M. Barzegar-Jalali, M.-H. Zarrintan, and K. Adibkia, "Physicochemical characterization and antimicrobial evaluation of gentamicin-loaded $\mathrm{CaCO}_{3}$ nanoparticles prepared via microemulsion method," Journal of Drug Delivery Science and Technology, vol. 35, pp. 16-23, 2016.

[38] S. Lagergren, "Zur theorie der sogenannten adsorption gelöster stoffe, Kungliga Svenska Vetenskapsakademiens," Handlingar, vol. 24, pp. 1-39, 1898.

[39] Y. S. Ho and G. McKay, "Pseudo-second order model for sorption processes," Process Biochemistry, vol. 34, no. 5, pp. 451-465, 1999.

[40] J. W. Weber and J. C. Morris, "Kinetics of adsorption on carbon from solution," Journal of the Sanitary Engineering Division, vol. 89, pp. 31-60, 1963.

[41] J.-P. Simonin, "On the comparison of pseudo-first order and pseudo-second order rate laws in the modeling of adsorption kinetics," Chemical Engineering Journal, vol. 300, pp. 254-263, 2016.

[42] A. Gurses, C. Dogar, M. Yalcin, M. Acikyildiz, R. Bayrak, and S. Karaca, "The adsorption kinetics of the cationic dye, methylene blue, onto clay," Journal of Hazardous Materials, vol. 131, no. 1-3, pp. 217-228, 2006.

[43] G. B. Oguntimein, "Biosorption of dye from textile wastewater effluent onto alkali treated dried sunflower seed hull and design of a batch adsorber," Journal of Environmental Chemical Engineering, vol. 3, no. 4, pp. 2647-2661, 2015.

[44] F. Bouhamed, Z. Elouear, and J. Bouzid, “Adsorptive removal of copper(II) from aqueous solutions on activated carbon prepared from Tunisian date stones: equilibrium, kinetics and thermodynamics," Journal of the Taiwan Institute of Chemical Engineers, vol. 43, no. 5, pp. 741-749, 2012.

[45] C. H. Giles, T. H. Macewan, S. N. Nakhwa, and D. Smith, "786. Studies in adsorption. Part XI. A system of classification of solution adsorption isotherms, and its use in diagnosis of adsorption mechanisms and in measurement of specific surface areas of solids," Journal of the Chemical Society (Resumed), vol. 3, pp. 3973-3993, 1960.

[46] D. Chen, J. Chen, X. Luan, H. Ji, and Z. Xia, "Characterization of anion-cationic surfactants modified montmorillonite and its application for the removal of methyl orange," Chemical Engineering Journal, vol. 171, no. 3, pp. 1150-1158, 2011. 